\title{
PERANCANGAN MODUL PEMBELAJARAN SENI LUKIS BAHAN PEWARNA ALAM MATA PELAJARAN SENI LUKIS PADA SISWA KELAS X.I DI SMAN 2 ENREKANG
}

\author{
Siti Aisyah, Benny Subiantoro, Pangeran Paita Yunus \\ Pendidikan Seni Rupa, Fakultas Seni dan Desain, Universitas Negeri Makassar \\ ichaaisyah513@gmail.com \\ bennysubiantoro@yahoo.com \\ pangeranpaita@yahoo.com
}

\begin{abstract}
Abstrak
Penelitian ini bertujuan untuk menghasilkan modul pembelajaran seni lukis bahan pewarna alam (kesumba) dalam mata pelajaran melukis untuk siswa kelas X.I di SMAN 2 Enrekang. Penelitian ini merupakan penelitian pengembangan (Research and Development/R\&D) dengan prosedur meliputi tahap: analisis kebutuhan, perancangan produk awal, pengembangan produk awal, validasi, revisi untuk penyempurnaan produk akhir. Tahap analisis dilakukan dengan mengumpulkan informasi tentang media ajar yang digunakan di SMAN 2 Enrekang, tahap peracangan produk awal dilakukan mencari referensi materi dan referensi pembelajaran yang menarik dan merancang desain modul menggunakan softwere computer (Corel Drow X7), validasi kemudian dilakukan oleh parah ahli terhadap modul pembelajaran yang telah dihasilkan sementara (produk awal), pada tahap refisi didapatkan dari berbagai masukan dosen pembimbing, dosen penguji dan ahli materi dan ahli media. Instrumen pengumpulan data menggunakan observasi, wawancara, dokumentasi dan angket validasi. Hasil penelitian dianalisis secara kuantitatif. Penelitian ini menghasilkan modul Melukis Menggunakan Bahan Pewarna Alam (Kesumba) yaitu modul lengkap (Self Contained), berukuran $17.5 \mathrm{~cm}$ x $25 \mathrm{~cm}$ dengan ketebalan kertas sampul 260gr dan isi modul menggunakan kertas MP 100gr disajikan secara portrait berisi 73 halaman awal (sampul depan belakang, kata pengantar, daftar isi, petunjuk penggunaan modul, tujuan pembelajaran, peta materi dan pendahuluan). Modul memuat materi menjadi empat bagian, yaitu materi I berisi pengertian seni, seni lukis, dan bahan pewarna alam (kesumba), materi II berisi pengenalan alat dan bahan membuat pewarna alam (kesumba), materi III berisi cara melukis menggunakan bahan pewarna alam (kesumba) dan materi IV berisi hasil melukis menggunakan bahan pewarna alam (kesumba). Dapat disimpulkan bahwa siswa kelas X.I di SMAN 2 Enrekang setuju menggunakan modul Melukis Menggunakan Bahan Pewarna Alam (Kesumba).
\end{abstract}

Kata kunci: modul pembelajaran, pewarna alam (kesumba)

\begin{abstract}
This study aims to produce a learning module of natural coloring materials (kesumba) in painting subjects for students of class X.I in SMAN 2 Enrekang. This research is a development research (Research and Development $/ R \& D$ ) with procedures covering the stages: needs analysis, initial product design, initial product development, validation, revision for final product improvement. The analysis phase was carried out by collecting information about teaching media used in SMAN 2 Enrekang, the initial product development stage was done looking for references of material and references of interesting learning and designing module design using computer software (Corel Drow X7), validation was then carried out by severe module experts learning that has been produced temporarily (initial product), at the refining stage is obtained from various inputs of supervisors, examiners and material experts and media experts. Data collection instruments using observation, interviews, documentation and validation questionnaires. The results of the study were analyzed quantitatively. This study produced a painting module using natural dyes (Self Contained), a self-contained module,
\end{abstract}


measuring $17.5 \mathrm{~cm} \times 25 \mathrm{~cm}$ with a thickness of $260 \mathrm{gr}$ cover paper and the contents of the module using MP 100gr paper presented in portrait containing 73 initial pages (back cover, preface, table of contents, module usage instructions, learning objectives, material maps and introduction). The module contains material into four parts, namely material I contains an understanding of art, painting, and natural dyes (kesumba), material II contains an introduction to tools and materials for making natural dyes (kesumba), material III contains how to paint using natural dyes (kesumba) and material IV contains the results of painting using natural dyes (kesumba). It can be concluded that the students of class X.I at SMAN 2 Enrekang agreed to use the Painting module Using Natural Dyes (Kesumba).

Keywords: learning modules, natural dyes (kesumba)

\section{PENDAHULUAN}

Mata pelajaran Seni Budaya mencakup enam cabang kesenian yaitu seni rupa, seni musik, seni tari, seni theater, seni sastra dan seni film (Subiantoro, 2014: 21). Seni rupa yaitu, salah satu cabang seni yang merupakan curahan daya cipta diwujudkan dalam bentuk dan rupa. Artinya dalam wujud yang dapat dilihat dengan mata serta dapat diraba. Dengan kata lain ekspresi atau curahan kreatif yang dikonkritkan dalam bentuk visual.

Seni lukis merupakan salah satu bidang keahlian dalam seni rupa. Dalam pembelajaran seni lukis di SMAN 2 Enrekang peserta didik diajarkan tentang penguasaan bentuk, teknik, alat dan bahan, tidak ketinggalan adalah penguasaan warna.

Warna merupakan unsur yang paling penting dalam objek desain. Karena dapat memberikan dampak psikologis, suasana bagi yang melihatnya, selain dengan warna seorang perancang bisa menampilkan identitas, menyampaikan pesan atau membedakan sifat dari bentuk visual secara jelas.

Selama ini pewarna yang sering digunakan dalam pembelajaran seni lukis di SMAN 2 Enrekang adalah pewarna sintesis. Pewarna sintesis merupakan zat warna yang berasal dari zat kimia yang bersifat racun dan tidak ramah lingkungan. Pewarna ini dikemas praktis dalam bentuk kemasan tube, botol, palet dan lain sebagainya. Namun pewarna sintetis tidak mudah ditemukan diberbagai tempat, umumnya hanya dijual di Kota-Kota Besar. Sedangkan di Kota kecil khususnya Enrekang biasanya hanya menyediakan pewarna sistetis dengan warna yang terbatas, karena kurangnya minat melukis bagi siswa khususnya di SMAN 2 Enrekang. Oleh kerena itu penulis mengajukan gagasan dalam penelitian ini yaitu dengan mencoba menggunakan pewarna alam (kesumba).

Penyampaian materi tentang seni lukis di SMAN 2 Enrekang masih memiliki penghambat. Salah satu faktor penghambat untuk penyampaian materi tersebut adalah minimnya media pembelajaran untuk penyampaian materi ajar. Umumnya guru hanya menggunakan media cetak berupa buku pembelajaran sebagai media ajar padahal materi pembelajaran yang disajikan secara konkret dirasa sangat bagus dalam pembelajaran seni terutama seni lukis, terlebih lagi melukis merupakan kegiatan pembelajaran yang cukup rumit. Selain perlu mengetahui dasar teori pembelajaran diperlukan juga peragaan atau praktik bagi guru agar siswa lebih mudah memahami materi tersebut.

Sedangkan tuntutan untuk mencapai tujuan pendidikan harus menciptakan proses pembelajaran yang dapat merangsang perkembangan peserta didik baik afektif, kongnitif, maupun psikomotor. Salah satu upaya pemecahan masalah-masalah yang ada pada pembelajaran seni lukis di SMAN 2 Enrekang dapat ditempuh dengan pemilihan media pembelajaran yang tepat. Salah satu bentuk media pembelajaran yang dapat digunakan adalah modul.

Tujuan yang ingin dicapai dalam penelitian ini adalah untuk menghasilkan modul pembelajaran seni lukis bahan pewarna alam (kesumba) dalam mata pelajaran melukis untuk siswa kelas X.I di SMAN 2 Enrekang.

Hasil penelitian ini diharapkan dapat memberikan manfaat baik teoritis maupun praktis bagi guru, siswa, peneliti, dan semua yang terkait dengan dunia pendidikan, adapun manfaatnya adalah: (1) Teoritis, penelitian pengembangan ini dapat dijadikan pedoman 
atau referensi awal bagi penelitian berikutnya yang ingin mengembangkan media pembelajaran. (2) Praktis: bagi siswa, Melalui penggunaan modul ini, peserta didik dapat lebih meningkatkan kreativitas dan produktif. Bagi guru, dengan modul ini, diharapkan menjadi sumber informasi dan masukan untuk pendidik sehingga dapat membantu pendidik dalam pembelajaran melukis menggunakan bahan pewarna alam (kesumba). Bagi peneliti, mendapatkan pengetahuan tentang seberapa efektif modul pembelajaran yang dikembangkan terhadap hasil belajar siswa.

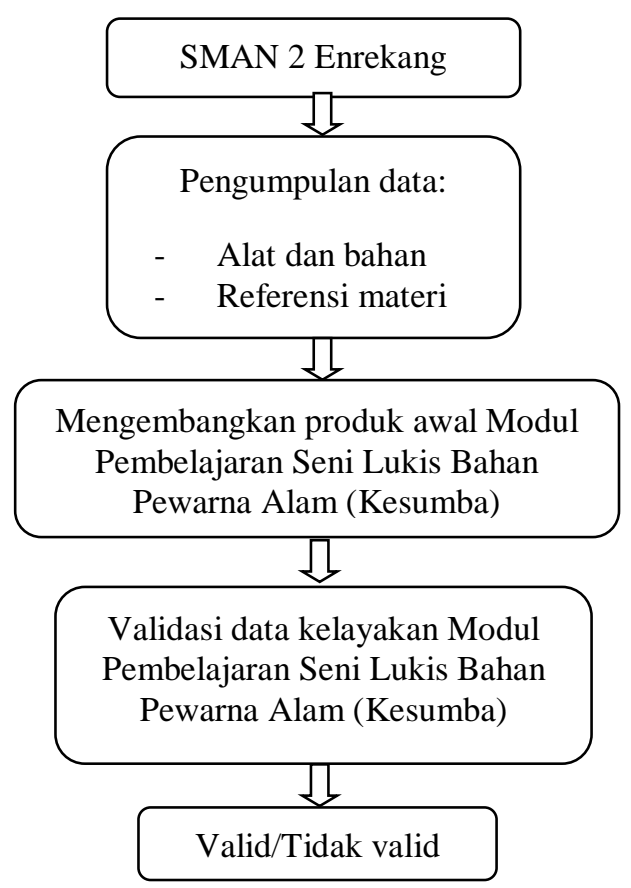

Gambar 1. Skema kerangka pikir

Djamaroh dan Zain (2002: 136) berpendapat, bahwa media adalah wahana penyalur informasi belajar atau penyalur pesan. Soeparno (1988: 1) berpendapat bahwa, media adalah suatu alat yang dipakai sebagai saluran (channel) untuk menyampaikan suatu pesan (message) atau informasi dari suatu sumber (resource) kepada penerima pesan (receiver). Sedangkan Rahadi (2003: 9) berpendapat, bahwa media adalah saluran komunikasi yang digunakan untuk menyampaikan pesan atau informasi. Berdasarkan pendapat dari berbagai ahli di atas, maka dapat ditarik kesimpulan bahwa media adalah alat bantu yang dapat berupa manusia, benda, alat, teknik, atau metode yang digunakan dalam proses pembelajaran. Media digunakan untuk menyampaikan informasi dari sumber kepada penerima sehigga dapat memperoleh pengetahuan atau wawasan keterampilan atau sikap.

a. Media sebagai alat bantu pembelajaran

Kehadiran media sebagai alat bantu dalam pembelajaran merupakan suatu kebutuhan yang penting dan tidak dapat dipungkiri. Kehadirannya, lebih ditentukan oleh kebutuhan guru untuk membentuk tugasnya dalam menyampaikan pesan-pesan dari materi ajar yang diberikan oleh guru kepada anak didiknya. Guru sadar bahwa tanpa bantuan media, maka materi yang rumit atau kompleks akan sukar dicerna atau dipahami peserta didik.

Sebagai alat bantu, media mempunyai fungsi dalam memperlancar menuju pencapaian tujuan pembelajaran. Hal ini, lebih didasarkan atas keyakinan dan secara rasional kita dapat menerima bahwa proses pembelajaran dengan bantuan media, yang makin mempertinggi daya rangsang atau dorongan keaktivan anak didik. Dengan demikian, akan menciptakan kesan dan ingatan yang dalam pada tenggang waktu yang cukup lama. Itu berarti kegiatan pembelajaran dengan bantuan media akan menghasilkan proses dan hasil belajar yang lebih baik daripada tanpa bantuan media.

Desain pembelajaran dapat dimaknai dari berbagai sudut pandang, misalnya sebagai disiplin, sebagai ilmu, sebagai sistem, dan sebagai proses. Sebagai disiplin, desain pembelajaran membahas berbagai penelitian dan teori tentang strategi serta proses pengembangan pembelajaran dan pelaksanaannya. Sebagai sistem, desain pembelajaran merupakan pengembangan sistem pembelajaran dan sistem pelaksanaannya termasuk sarana serta prosedur untuk meningkatkan mutu belajar. Sementara itu desain pembelajaran sebagai proses menurut Sagala (2005: 136) adalah pengembangan pengajaran secara sistematik yang digunakan secara khusus teori-teori pembelajaran untuk menjamin kualitas pembelajaran. Pernyataan tersebut mengandung arti bahwa penyusunan perencanaan pembelajaran harus sesuai dengan konsep pendidikan dan pembelajaran 
yang dianut dalam kurikulum yang digunnakan.

Dengan demikian dapat disimpulkan desain pembelajaran adalah praktik penyusunan media teknologi komunikasi dan isi untuk membantu agar dapat terjadi transfer pengetahuan secara efektif antara guru dan peserta didik.

a. Teori-teori pembelajaran dalam desain pembelajaran

Teori pembelajaran: (a) Teori behaviorisme. (b) Teori kongnitivisme (c) Teori konstruktivisme.

b. Model desain pembelajaran

Adanya variasi model desain pembelajaran yang ada sebenarnya juga dapat menguntungkan kita, beberapa keuntungan itu antara lain adalah kita dapat memilih dan menerapkan salah satu model desain pembelajaran yang sesuai dengan karakteristik yang kita hadapi di lapangan, selain itu juga, kita dapat mengembangkan dan membuat model turunan dari model-model yang telah ada, ataupun kita juga dapat meneliti dan mengembangkan desain yang telah ada untuk dicobakan dan diperbaiki.

Berikut beberapa contoh dari modelmodel desain pembelajaran: (a) Model Dick and Carrey. (b) Model Kemp. (c) Model ASSURE. (d) Model ADDIE. (e) Model Hanafin and Peck.

Modul merupakan unit lengkap yang berdiri sendiri dan terdiri atas rangkaian kegiatan belajar yang disusun untuk membantu siswa mencapai sejumlah tujuan yang telah dirumuskan secara khusus dan jelas (Nasution, 2003: 205). Sedangkan Pamadhi (2011: 1) menjelaskan kata modul dalam pembelajaran, mendapat inspirasi dari kata lunar module, yaitu sebuah pesawat terbang luar angkasa bernama Lunar. Pesawat ini diinstruksi oleh stasiun pengontrol di bumi. Selanjutnya ide ini dimanfaatkan dalam strategi mendidik, yaitu merancang suatu pembelajaran yang diarahkan dan dikontrol dari jarak jauh.

Dengan demikian modul pembelajaran adalah salah satu jenis strategi pembelajaran yang mampu memberikan rangsangan belajar mandiri. Manfaat modul pembelajaran adalah mengatasi keterbatasan guru dalam segala hal termasuk mengejar percepatan ilmu pengetahuan dan teknolgi. a. Karakterisitik Modul

Modul mempunyai beberapa karakteristik tertentu, misalnya berbentuk unit pengajaran terkecil, lengkap dan berisi rangkaian kegiatan belajar yang dirancang secara sistematis, berisi tujuan belajar yang dirumuskan secara jelas dan khusus, memungkinkan siswa belajar mandiri, dan merupakan realisasi perbedaan individual. Sebuah modul bisa dikatakan baik dan menarik apabila terdapat karakteristik sebagai berikut: (1) Pembelajaran mandiri (self instructional). (2) Kesatuan isi (self contained). (3) berdiri sendiri (stand alone). (4) Adaptif (adaptive). (5) Bersahabat dengan penggguna (userfriendly)

Salam (2001: 4) menjelaskan bahwa seni lukis adalah karya yang dihasilkan melalui goresan warna yang berukuran lebar yang dihasilkan menggunakan alat kuas, palet, tabung cat (pilox), telapak tangan dan jari-jari. Seni lukis menurut Sunaryo dan Sumartono (2006: 3) diartikan sebagai ungkapan perasaan dan pikiran pada suatu bidang datar melalui susunan garis, bidang atau raut, tekstur, dan warna atas hasil pengamatan dan pengalaman estesis seseorang. Media yang umum digunakan dalam melukis yaitu dari bahan sintesis seperti cat air, cat akrilik, crayon, cat minyak dan lain sebagainya.

Seni lukis merupakan salah satu program keahlian di SMAN 2 Enrekang. Bidang pembelajaran praktik yang dipelajari meliputi; sketsa, gambar bentuk, ornamen, seni lukis modern dan seni lukis tradisional. Pembelajaran seni lukis untuk siswa kelas X.I pada semester II meliputi: (1) Pengenalan alat dan bahan melukis dengan teknik basah berwarna. (2) Pemahaman objek sesuai dengan bentuk dan karakternya. (3) Pemahaman prosedur melukis teknik basah berwarna. (4) Membuat lukisan dengan teknik basah menggunakan pewarna alam (kesumba).

Dalam kamus lengkap Bahasa Indonesia dijelaskan bahwa, bahan adalah barang yang akan dibuat menjadi satu benda tertentu. Sedangkan alam adalah merupakan segala yang ada di langit dan di bumi termasuk di lingkungan sekitar kita.

Jadi bahan alam adalah bahan yang diambil dari alam sekeliling kita serta dapat diolah menjadi berbagai macam seperti kayu 
imajinàsi

dapat diolah menjadi bangunan, bangku dan lain-lainnya. Adapun tumbuh-tumbuhan dapat diolah menjadi menjadi jamu dan obat-obatan, tumbuh-tumbuhan juga dapat dijadikan pewarna untuk melukis.

Warna adalah unsur seni rupa yang paling menonjol dalam karya seni rupa. Warna bisa menunjukkan gelap terang, suasana perasaan atau lambang, jauh dekat, perspektif serta sifat atau watak benda. Dalam teori warna menurut ilmu Fisika adalah kesan yang ditimbulkan oleh cahaya pada mata. Sedangkan warna yang berasal dari dasar sumber alam, yaitu ketergantugan dari pigmen yang melekat pada permukaan luar dan bagian dalam benda atau alam itu sediri.

Contoh lukisan dari pewarna alam karya Benny Subiantoro:

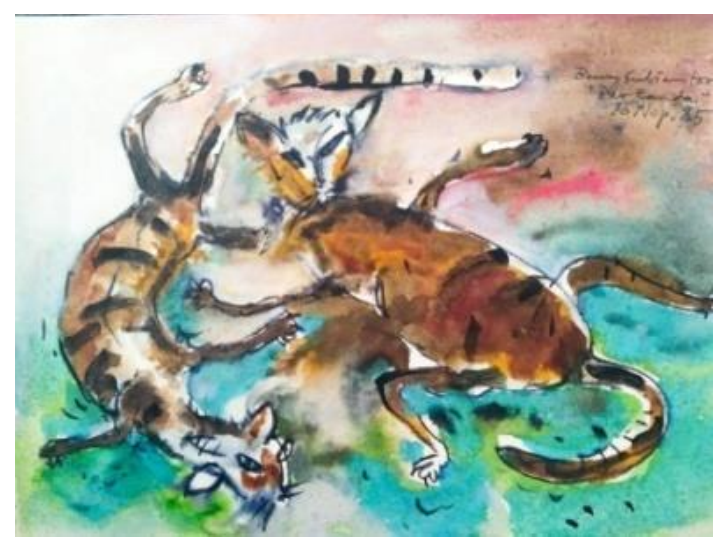

Gambar 4. "Bersenda Gurau", di atas media kertas. 1983. Ukuran 25 x 15 cm. Karya: Benny Subiantoro

\section{METODE PENELITIAN}

Desain penelitian yang berjudul Modul Pembelajaran Seni Lukis Bahan Pewarna Alam Mata Pelajaran Seni Lukis Pada Siswa Kelas X.I Di SMAN 2 Enrekang ini mengacu pada jenis penelitian Research and Development yaitu penelitian dan pengembangan (R\&D).

Brog \& Gall (1987: 772) memberikan definisi penelitian dan pengembangan pendidikan sebagai berikut: "Educational research and development is a process used to develop and validate educational product". Penelitian dan pengembangan pendidikan adalah proses yang digunakan untuk mengembangkan dan memvalidasi produkproduk pendidikan.
Penelitian ini dilaksanakan di SMAN 2 Enrekang Jalan Jenderal Sudirman No. 9, Galonta, Kecematan Enrekang, Kabupaten Enrekang Provinsi Sulawesi Selatan. Pelaksanaanya direncanakan mulai bulan April 2018.

Objek penelitian dalam pengembangan (R\&D) ini adalah pengembangan modul pembelajaran seni lukis tentang melukis menggunakan pewarna dari bahan alam (kesumba).

Prosedur penelitian pengembangan akan memaparkan prosedur yang ditempuh oleh peneliti/pengembang dalam membuat produk. Prosedur pengembangan modul belajar melukis menggunakan pewarna alam (kesumba) untuk pembelajaran melukis di SMAN 2 Enrekang yaitu dengan menggunakan model Brog and Gall, berikut langkahnya:

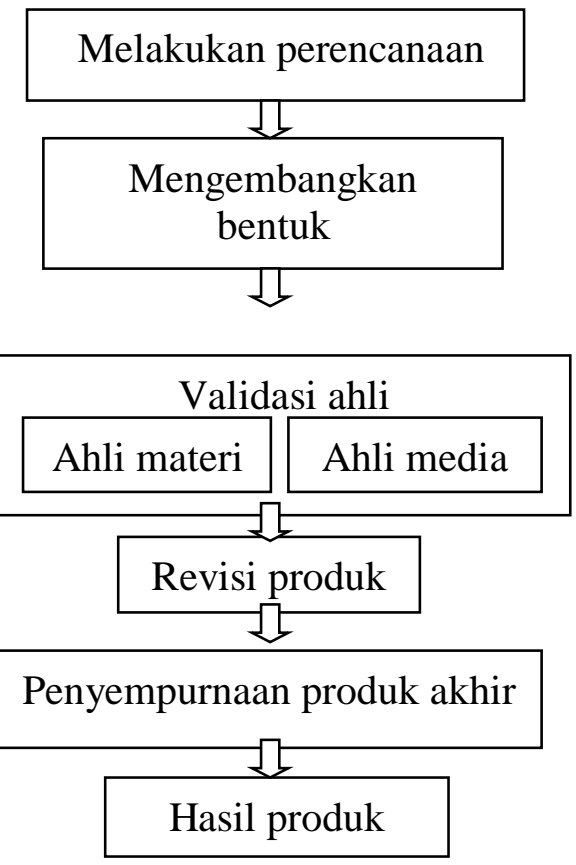

Gambar 18. Langkah Pengembangan

Teknik pengumpulan data yang digunakan berupa wawancara, dokumentasi dan angket validasi.

Metode wawancara merupakan metode pengumpulan data dengan cara tanya jawab yang sistematis dan berdasarkan pada tujuan penelitian. Metode wawancara dilakukan sebagai bahan awal peneliti untuk mengetahui masalah atau kendala yang ditemui dalam pembelajaran. Teknik wawancara pada peelitian ini dilakukan pada guru mata 
pelajaran Seni Lukis dan siswa kelas X.1 di SMAN 2 Enrekang.

Metode dokumentasi dilakukan dengan mencari data mengenai hal-hal yang berupa catatan, buku, dan dokumen untuk mengumpulkan teori atau pendukung. Instrument berupa RPP dan Silabus.

Angket atau kuesioner adalah daftar pertanyaan atau pernyataan untuk mengumpulkan data/informasi dari responden. Angket merupakan teknik pengumpulan data yang dilakukan dengan cara memberikan seperangkat pertanyaan atau pernyataan tertulis kepada responden untuk dijawab. Angket digunakan sebagai alat ukur penilaian modul dalam tahap uji coba lapangan. Angket penilaian akan diberikan kepada validator yaitu ahli materi dan ahli media, untuk menilai kelayakan modul yang telah mereka pelajari.

Teknik analisis data yang digunakan untuk mengolah data yang diperoleh dalam pengembangan modul Melukis Menggunakan Bahan Alam (Kesumba) ini adalah dengan menggunakan teknik analisis data kuantitatif deskriptif dengan rumus distribusi presentase (Arikunto, 2006:246).

$$
\mathrm{P}=\frac{f}{N} \times 100
$$

Keterangan:

$\mathrm{f}=$ Frekuensi yang sedang dicari presentasenya (skor yang didapat). $\mathrm{N}=$ skor maksimal (Number of Case). $\mathrm{P}=$ hasil presentase.

Setelah diperoleh presentase dengan rumus tersebut, kemudian penelitian menafsirkan hasil presentase dengan kriteria keefektifan, yaitu baik, cukup baik, kurang baik, dan tidak baik. 76 - 100\% baik, $56-$ $75 \%$ cukup baik, $40-55 \%$ kurang baik, < $40 \%$ tidak baik.

Kategori kelayakan modul dalam penelitian pengembangan ini ditetapkan nilai kelayakan modul minimal dengan kategori "Baik". Sehingga hasil penelitian dan penilaian yang diperoleh dari ahli materi dan ahli media mencapai nilai "Baik" maka modul yang dikembangkan sudah dianggap "Baik digunakan".

\section{HASIL DAN PEMBAHASAN}

\subsection{Prosedur Pengembangan Modul}

\subsection{Analisis Kebutuhan}

Tahap penelitian awal pengembangan yang dilakukan di SMAN 2 Enrekang adalah metode wawancara kepada guru mata pelajaran Seni Lukis kelas X.I dan beberapa siswa kelas X.I. Tahap ini merupakan tahap awal yang dilakukan untuk memperoleh data tentang permasalahan yang ada pada pembelajaran seni lukis.

\subsection{Perancangan Modul Pembelajaran}

Tahap perencanaan awal peneliti melakukan diskusi dengan Dosen Pembimbing tentang konsep model yang akan dikembangkan. Tahap kedua, peneliti melakukan diskusi dengan Dosen Pembimbing mengenai materi modul yang akan disusun. Tahap ketiga, peneliti melakukan studi pustaka dari berbagai sumber (buku dan internet). Tahap keempat, peneliti menyiapkan alat penyusunan modul. Penyusunan modul menggunakan sofwere computer, diantaranya Miccrosoft Office 2007, Corel Draw X7 dan Photoshop. Tahap kelima, peneliti membuat desain sampul modul, dan dikonsultasikan kepada pembimbing. Tahap keenam, peneliti membuat sketsa dan pembagian zoning area pada desain sampul depan dan sampul belakang, serta isi modul.

\subsection{Pengembangan Produk Awal}

Pada tahap ini peneliti membuat bentuk produk awal modul dengan materi Melukis Menggunakan Bahan Alam (Kesumba). Langkah-langkah yang dilakukan adalah menyiapkan peralatan/bahan untuk membuat modul. Peralatan yang digunakan adalah; satu unit computer, alat tulis, printer dan scanner, kamera digital. Kemudian menyusun penulisan modul meliputi desain cover modul dan isi modul.

Tahap pengembangan awal yang dilakukan peneliti dalam membuat modul "Melukis Menggunakan Bahan Pewarna Alam (Kesumba)" yaitu, sampul depan modul, kata pengantar, daftar isi, petunjuk penggunaan modul, tujuan pembelajaran, peta materi, pendahuluan, sampul pembatas materi I, materi I, rangkuman materi I, sampul pembatas materi II, materi II, rangkuman 
materi II, sampul pembatas materi III, materi III, sampul pembatas materi IV, materi IV, latihan, evaluasi, kunci jawaban, daftar pustaka, profil penulis dan sampul belakang modul.

Produk awal berupa modul pembelajaran melukis menggunakan bahan pewarna alam (kesumba). Desain produk yang telah jadi kemudian ditunjukkan kepada dosen pembimbing untuk mendapatkan saran dan masukan sampai layak untuk divalidasi oleh ahli materi dan ahli media untuk mendapat penilaian serta saran dan masukan.

\subsection{Validasi}

Validasi oleh ahli materi dan ahli media dilakukan dengan pengisian angket yang meliputi lembar penilaian serta lembar masukan dan saran. Angket sebagai instrumen dibuat sesuai dengan karakteristik modul pembelajaran yang baik, baik ditinjau dari segi pembelajaran, materi/isi dan tampilan desain modul. Pembuatan instrumen dikonsultasikan pada dosen pembimbing sampai angket penelitian dinilai valid dalam menilai kualitas modul pembelajaran.

Ahli materi dan ahli media dilakukan dengan memperkenalkan dan menunjukkan modul pembelajaran dan dilanjutkan dengan pengisian angket yang merupakan instrumen penelitian. Validasi bertujuan untuk mendapatkan penilaian, saran dan masukan sebagai bahan pertimbangan. Validasi bahan ajar berupa modul pembelajaran Melukis Menggunakan Bahan Pewarna Alam (Kesumba).

Pada tahap awal validasi, penulis merevisi produk berdasarkan saran para ahli dan melakukan penilaian sampai kelayakan modul dapat nilai presentase 56\%-75\% atau masuk kategori layak. Nilai presentase didapat dari penggunaan rumus presentase Arikunto, $\mathrm{P}=$ $\mathrm{f} / \mathrm{N} \times 100 \%$ terhadap penilaian aspek kelayakan modul.

\section{SIMPULAN DAN SARAN}

\subsection{Kesimpulan}

Berdasarkan hasil penelitian dapat ditarik kesimpulan, modul yang dikembangkan dengan judul "Melukis Menggunakan Bahan Pewarna Alam (Kesumba)" untuk siswa kelas X.1 SMAN 2 Enrekang adalah modul lengkap (Self Contained) berukuran $17.5 \mathrm{~cm}$ x $25 \mathrm{~cm}$ dengan sampul Ivory ketebalan 260gr disajikan secara portrait dan isi modul menggunakan kertas dengan ketebalan 100gr disajikan secara portrait berisi sebanyak 73 halaman isi materi dan 7 halaman awal (sampul depan belakang, kata pengantar, daftar isi, petunjuk penggunaan modul, tujuan pembelajaran, peta materi dan pendahuluan). Isi materi dibagi menjadi empat bagian yaitu, materi I berisi pengertian seni, seni lukis, dan bahan pewarna alam, materi II berisi pengenalan alat dan bahan membuat pewarna alam (kesumba), materi III berisi cara melukis menggunakan bahan pewarna alam (kesumba), dan materi IV berisi hasil melukis menggunakan bahan pewarna alam (kesumba).

Modul melukis menggunakan bahan pewarna alam (kesumba) ini telah memenuhi kriteria kualitas berdasarkan saran dan masukan dari dosen pembimbing, ahli materi dan ahli media. Modul pembelajaran meliputi tahap analisis kebutuhan, perencanaan, pengembangan, validasi desain produk, dan revisi desain produk.

Modul telah melewati tahap validasi, dan telah memenuhi kriteria kelayakan media pembelajaran. Dengan perolehan presentase dari ahli materi sebesar 94\%, dari ahli media $76 \%$. Berdasarkan penilaian ahli media dan ahli materi, maka rata-rata penilaian secara keseluruhan adalah sebesar $85 \%$ atau termasuk kategori layak sebagai media pembelajaran.

\subsection{Saran}

Produk modul pembelajaran melukis menggunakan bahan pewarna alam (kesumba) yang telah dikembangkan perlu diterapkan langsung dalam kegiatan pembelajaran di kelas X.1 SMAN 2 Enrekang. Hal ini bertujuan untuk mengetahui sejauh mana pengaruh dan keefektifan media pembelajaran Interaktif terhadap hasil belajar siswa dalam bentuk karya lukis. Modul pembelajaran ini dapat digunakan dan dikembangkan lebih lanjut dalam proses pembelajaran yang melibatkan guru dan siswa. Produk serupa juga dapat dibuat dan dikembangkan untuk pembelajaran seni rupa lainnya, agar hasil dari penelitian tersebut dapat digunakan dalam proses pembelajaran bagi siswa dan memperkaya bahan ajar. 
Aisyah, Subiantoro, Yunus: Perancangan Modul Pembelajaran Seni Lukis Bahan Pewarna Alam Mata Pelajaran Seni Lukis Pada Siswa Kelas X.I di SMAN 2 Enrekang

\section{Daftar Pustaka}

Arikunto, Syharsimi.2006. prosedur Penelitian Suatu Pendekatan Praktik. Jakarta: Rineka Cipta.

Brog, W.R \& Gall, M.D. 1987. Educational Research: An Intraduction. Jakarta: PAU-PPAIN Universitas Terbuka.

Nasution, S. 2003. "Berkebun Buah Naga". Skripsi: Surabaya, FBS Unesa.

Pamadi, Hajar. 2011. Workshop Penulisan Modul Bagi Guru SMA Negeri 1 Dlingo. Jakarta: Rineka Cipta.

Salam, Sofyan. 200. Seni Rupa Mimesis dan Modern/Kontemporer di Sulawesi Selatan (Sebuah Pengantar Tentang Perjalanan Dan Persoalannya). Makassar: DKKS Makassar

Subiantoro, Benny. 2014. Mudahnya Belajar Mrenggambar Media Pembelajaran Seni Budaya Guru Sekolah Taman Kanak-Kanak dan Guru Sekolah Dasar (PGMI). Makassar: Pendidikan Sekolah Dasar (PGMI) Universitas Islam Negeri.

Sunaryo dan Sumartono. 2006. "Seni Lukis Dasar (Bahan Ajar Seni Lukis I)". Skripsi: Surabaya, FBS Unesa.

Zain, S. B. 2006. Strategi Belajar Mengajar. Jakarta: Bineka Cipta. 